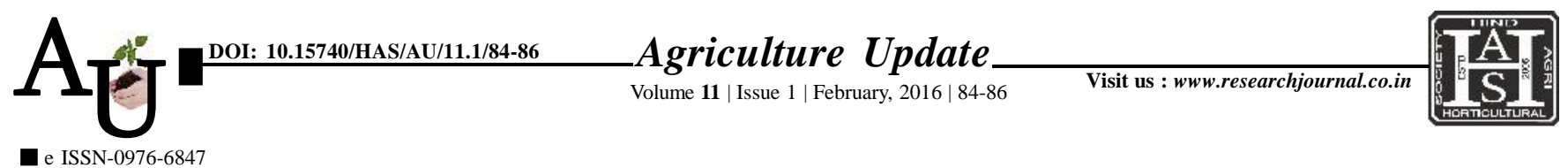

\title{
Reser rсн Note: Focus on mode of employment in Arajilines block of Varanasi, U.P.
}

\section{OM PRAKASH}

Article Chronicle: Received :

27.08.2015;

Accepted :

27.01.2016

KEY WoRDS:

Employment, Villages,

Service, Mixed

farming, Arajilines
Author for correspondence :

\section{OM PRAKASH}

Department of Animal Husbandry and Dairying, Amar Singh (P.G.)

College, Lakhaoti, BULANDSHAHR (U.P.) INDIA
SUMMARY : Four villages of Arajilines block of Varanasi district were selected for the survey and collected information on employment against farmers. The employment against farmers were observed as service, mixed farming, service plus farming, service plus livestock farming and service plus mixed farming, in 9.24, 20.08, 11.65, 5.69 and 53.41 per cent, respectively. Significant $(\mathrm{P}<0.05)$ difference between various modes of employment was observed.

How to cite this article : Prakash, Om (2016). Focus on mode of employment in Arajilines block of Varanasi, U.P. Agric. Update, 11(1): 84-86. 